\title{
The role of lymphadenectomy in accurate staging and treatment of endometrial cancer
}

\author{
Rola limfadenektomii w dokładnej ocenie stopnia zaawansowania i leczeniu raka endometrium
}

\author{
Department of Minimally Invasive Surgery, Kyiv City Clinical Oncology Centre, Kyiv, Ukraine \\ Correspondence: Olena Postupalenko, Department of Minimally Invasive Surgery, Kyiv City Clinical Oncology Centre, Verkhovynna str. 69, 03115 Kyiv, Ukraine, \\ tel.: +380664172297, e-mail: a.v.postupalenko@gmail.com
}

\begin{abstract}
Aim of the study: Inaccurate lymph node staging affects treatment planning and may contribute to worse prognosis. A retrospective study was performed to confirm this hypothesis. Materials and methods: Data about patients diagnosed with stage I-III endometrial cancer between January 1, 2008 and December 31, 2009 (cases with multiple primary tumors were excluded) was extracted from cancer register of Kyiv City Clinical Oncology Centre. Hypothesis: The absence of lymphadenectomy in a patient with apparent early stage endometrial cancer, but with undiagnosed lymph node metastases may lead to understaging and undertreatment with worse prognosis and outcomes. Cancer-specific survival was the primary outcome. Results: From 564 patients assessed for eligibility, 61 were excluded. Cancer-related death was reported in 76 cases: 39 stage I, 14 - stage II, and 23 - stage III patients. Median cancer-specific survival was 27 months for stage I, 14 months for stage II, and 19 months for stage III $(p=0.01)$. Three-year cancer-specific survival rate was $33.3 \%$ for stage I, $0 \%$ for stage II, and $17.4 \%$ for stage III. Intergroup analysis showed a statistically significant difference in survival between stage I and stage II patients $(p=0.005)$, but there was no statistically significant difference in survival between stage III and stage I or II patients ( $p=0.072$ and $p=0.151$, respectively). Conclusions: The same rates of cancer-specific survival may indicate that the presented cases of apparently early stage endometrial cancer were understaged and consequently undertreated. Further studies in larger groups of patients are needed.
\end{abstract}

Keywords: endometrial neoplasms, mortality, diagnosis, therapeutics

Streszczenie Cel badania: Niedokładna ocena stopnia zaawansowania na podstawie zajęcia węzłów chłonnych wpływa na planowanie leczenia i może przyczynić się do pogorszenia rokowania. W celu potwierdzenia tej hipotezy przeprowadzono badanie retrospektywne. Materiał i metody: Z rejestru chorób nowotworowych Centrum Onkologii Klinicznej w Kijowie pozyskano dane dotyczące pacjentek, u których w okresie od 1 stycznia 2008 do 31 grudnia 2009 roku rozpoznano raka endometrium w stopniu zaawansowania I-III. Hipoteza: Pominięcie limfadenektomii u pacjentki w pozornie wczesnym stadium raka endometrium, ale z nierozpoznanymi przerzutami do węzłów chłonnych może skutkować zaniżeniem stopnia zaawansowania klinicznego oraz zastosowaniem niedostatecznego leczenia, a zatem pogorszeniem rokowania i wyników leczenia. Głównym punktem końcowym badania było przeżycie swoiste dla raka. Wyniki: Spośród 564 pacjentek ocenianych pod kątem włączenia do badania wykluczono 61 kobiet. Śmiertelność związaną z rakiem odnotowano w 76 przypadkach: 39 w stadium I, 14 w stadium II i 23 w stadium III. Mediana przeżycia swoistego dla raka wynosiła 27 miesięcy dla stopnia I, 14 miesięcy dla stopnia II i 19 miesięcy dla III stopnia zaawansowania ( $p=0,01$ ). Wskaźnik 3-letniego przeżycia swoistego dla raka oszacowano na 33,3\% dla stopnia I, 0\% dla stopnia II i 17,4\% dla stopnia III. Analiza międzygrupowa wykazała statystycznie istotną różnicę w zakresie przeżycia między pacjentkami w stadium I i II $(p=0,005)$, jednak różnicy takiej nie stwierdzono między pacjentkami ze stopniem zaawansowania III a stopniem I lub II (odpowiednio $p=0,072$ i $p=0,151$ ). Wnioski: Takie same wartości wskaźnika przeżycia swoistego dla raka mogą oznaczać, że przedstawione przypadki pozornie wczesnego stadium raka endometrium charakteryzowały się zaniżonym stopniem zaawansowania klinicznego, a zatem były niedostatecznie leczone. Konieczne jest przeprowadzenie dalszych badań $\mathrm{z}$ udziałem większych grup pacjentek.

Słowa kluczowe: rak endometrium, śmiertelność, rozpoznanie, leki 


\section{INTRODUCTION}

$\mathrm{E}$ ndometrial cancer is the most common gynecologic malignancy in Europe, Northern America and Oceania. Generally, it is considered to have a more favorable prognosis compared to cervical or ovarian cancer, but due to its heterogeneous biology there are still many questions about its diagnosis and treatment. Regional lymph node assessment is one of them.

Lymph node status affects the choice of adjuvant treatment and ontological prognosis. Survival rates of patients with endometrial cancer are significantly reduced if there is pelvic and/or lumbar lymph node involvement (5-year disease-free survival is $55-70 \%$ and $30-50 \%$, respectively) ${ }^{(1-3)}$.

Hypothetically, missed lymphadenectomy in a patient with apparent early stage endometrial cancer but with undiagnosed lymph node metastases may lead to understaging and undertreatment with worse prognosis.

\section{MATERIALS AND METHODS}

A retrospective study was performed based on the data of Kyiv City Clinical Oncology Centre cancer register. Eligibility criteria for participants: diagnosed stage I-III endometrial cancer between January 1, 2008 and December 31, 2009 (cases with multiple primary tumors were excluded). Cancer-specific survival was the primary outcome. SPSS Statistics 17.0 was used. Methods of variation statistics for quantitative (median, mean square deviation) and qualitative $(n, \%)$ characteristics were used during statistical data processing. Cancer-specific survival was determined with Kaplan-Meyer curves with log-rank test for difference estimation. Differences were assessed as statistically significant at $p<0.05$.

\section{RESULTS}

From 564 patients assessed for eligibility, 61 were excluded. Cancer-related death was reported in 76 cases. Before drawing any further conclusions, it is important to consider a small sample size and, consequently, make conclusions about possible tendency instead of significance.

The mean age at diagnosis was $67.83 \pm 10.24$ years (from 43 to 89 years). Stage I cancer was diagnosed in 39 patients (51\%), stage II - in 14 (19\%), and stage III - in $23(30 \%)$. Median survival rates were 27 months ( $95 \%$ confidence interval, CI 19.7-34.3), 14 months (95\% CI 12.2-15.8) and 19 months (95\% CI 14.3-23.7), respectively. These differences between survival rates were statistically significant $(p=0.01)$, but further intergroup analysis showed that there was a statistically significant difference in survival between stage I and stage II patients $(p=0.005)$, and that there were no statistically significant differences in survival between stage III and stage I or II patients ( $p=0.072$ and $p=0.151$,

\begin{tabular}{|c|c|c|c|c|c|c|c|c|}
\hline \multirow{3}{*}{ Stage } & \multicolumn{4}{|c|}{ Cancer-specific survival } & \multicolumn{3}{|c|}{$\boldsymbol{p}$ (intergroup) } \\
\cline { 2 - 5 } & $\boldsymbol{n}$ & $\begin{array}{c}\text { 3-year } \\
\text { [\%] }\end{array}$ & Median & $\mathbf{9 5 \%}$ CI & $\boldsymbol{p}$ & $\begin{array}{c}\text { Stage } \\
\text { I }\end{array}$ & $\begin{array}{c}\text { Stage } \\
\text { II }\end{array}$ & $\begin{array}{c}\text { Stage } \\
\text { III }\end{array}$ \\
\hline I & 39 & 33.3 & 27 & $19.7-34.3$ & & - & 0.005 & 0.072 \\
\hline II & 14 & 0 & 14 & $12.2-15.8$ & 0.01 & 0.005 & - & 0.151 \\
\hline III & 23 & 17.4 & 19 & $14.3-23.7$ & & 0.072 & 0.151 & - \\
\hline
\end{tabular}

Tab. 1. Survival data among dead patients with different stages of endometrial cancer

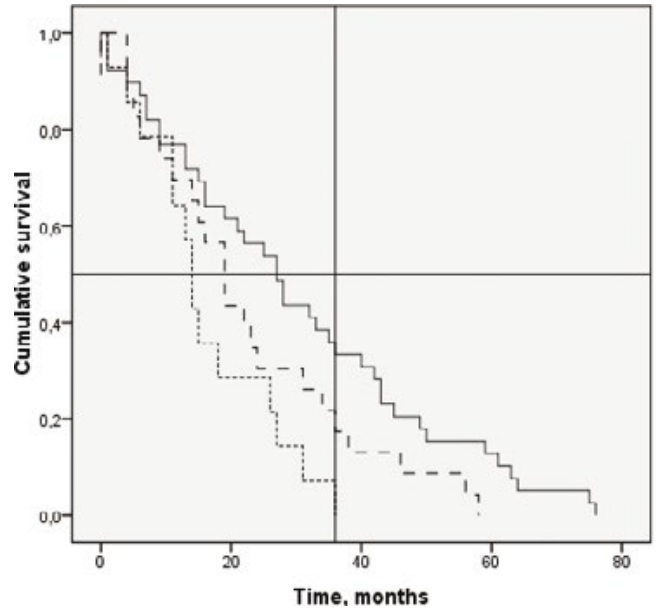

\begin{tabular}{c} 
Stage \\
- II \\
$\ldots$ - III \\
\hline- III
\end{tabular}

Fig. 1. Cancer-specific survival for different stages of endometrial cancer

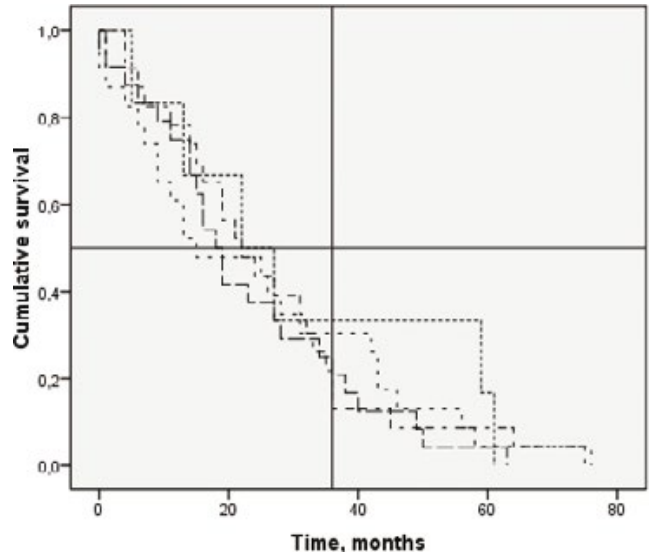

Fig. 2. Cancer-specific survival for different grades of endometrial cancer

$33.3 \%$ for stage I and $17.4 \%$ for stage III patients. None of patients with apparent stage II endometrial cancer who died from cancer lived more than 3 years. Survival data are summarized in Tab. 1 and illustrated in Fig. 1.

Tumor grade is a commonly known prognostic factor, and it was included in the analysis. There were 6 grade I (8\%), 23 grade II (30\%), and 24 grade III (32\%) patients; no data was available in 23 (30\%) patients. Median survival rates were 22 months (95\% CI 5.2-38.8), 15 months (95\% CI 0-31.4), 18 months (95\% CI 14.2-29.8) and 22 months (95\% CI 13.7-24.3), respectively. These differences between survival rates were not statistically significant generally $(p=0.826)$ and after intergroup analysis (Tab. 2, Fig. 2). 


\begin{tabular}{|c|c|c|c|c|c|c|c|c|c|}
\hline \multirow{2}{*}{ G } & \multicolumn{5}{|c|}{ Cancer-specific survival } & \multicolumn{4}{|c|}{$p$ (intergroup) } \\
\hline & $n$ & 3-year [\%] & Median & $95 \% \mathrm{Cl}$ & $p$ & GI & GII & G III & ND \\
\hline 1 & 6 & 33.3 & 22 & $5.2-38.8$ & \multirow{4}{*}{0.826} & - & 0.442 & 0.443 & 0.808 \\
\hline II & 23 & 30.4 & 15 & $0-31.4$ & & 0.442 & - & 0.186 & 0.824 \\
\hline III & 24 & 20.8 & 18 & $14.2-29.8$ & & 0.443 & 0.186 & - & 0.572 \\
\hline ND & 23 & 13.0 & 22 & $13.7-24.3$ & & 0.808 & 0.824 & 0.572 & - \\
\hline
\end{tabular}

Tab. 2. Survival data among dead patients with different grade of endometrial cancer

The role of each treatment component was analyzed for stage I-II cases both with and without stage III patients (Tabs. 3 and 4, respectively). It was shown that surgery and chemotherapy had no effect on survival in this cohort of patients. Significant improvement of survival was observed in patients who received radiotherapy for endometrial cancer. These patterns were almost the same for the analysis with or without the group of stage III patients.

\section{DISCUSSION}

The same rates of cancer-specific survival may indicate that the presented cases of apparent early stage endometrial cancer were understaged and consequently undertreated. The main limitation of this study was a small cohort of patients. Further studies enrolling more patients are needed. Another important fact is that diagnostic considerations in 2008-2009 and 2019 differ due to the wide implementation of computed tomography and improvement of ultrasound technologies, which may improve staging. It may be interesting to analyze their influence on lymph node staging, treatment considerations and survival. According to Society of Gynecologic Oncology (SGO) recommendations $(2014)^{(4)}$ and European Society for Medical Oncology, European Society of Gynaecological Oncology and European SocieTy for Radiotherapy \& Oncology (ESMOESGO-ESTRO) consensus (2016) ${ }^{(5)}$, computer tomography is inappropriate for routine examination of endometrial cancer patients.

We observed a tendency that lymph node metastasis became more frequent according to the reports in world literature. For example, Creasman et al. ${ }^{(6)}$ reported that $11 \%$ of endometrial cancer patients had lymph node metastasis. In more recent publications, Mariani et al. ${ }^{(7)}$

\begin{tabular}{|c|c|c|c|c|c|c|}
\hline \multirow{2}{*}{ Treatment* } & \multicolumn{5}{|c|}{ Cancer-specific survival (all cases) } \\
\cline { 3 - 7 } & & $n$ & 3-year [\%] & Median & 95\% Cl & $\boldsymbol{p}$ \\
\hline \multirow{2}{*}{ Surgery } & Yes & 44 & 27.3 & 22 & $15.5-28.5$ & \multirow{2}{*}{0.668} \\
\cline { 2 - 7 } & No & 32 & 15.6 & 19 & $10.2-27.9$ & \\
\hline \multirow{2}{*}{ Radiotherapy } & Yes & 60 & 26.7 & 25 & $18.7-31.3$ & \multirow{2}{*}{0.003} \\
\cline { 2 - 6 } & No & 16 & 6.1 & 11 & $3.2-18.8$ & \\
\hline \multirow{2}{*}{ Chemotherapy } & Yes & 23 & 17.4 & 18 & $14.9-21.1$ & \multirow{2}{*}{0.574} \\
\cline { 2 - 6 } & No & 53 & 24.5 & 25 & $16.9-33.2$ & \\
\hline \multirow{2}{*}{ * No cancer-related treatment in 5 patients. } \\
\hline
\end{tabular}

Tab. 3. Survival data among dead patients with different components of endometrial cancer treatment and Widschwendter et al. ${ }^{(8)}$ reported that this rate was $22-24.8 \%$. This may be due to the more precise morphological diagnosis or changes in the behavior of endometrial cancer, or both.

Routine systemic lymphadenectomy has no benefit for survival (MRC ASTEC trial ${ }^{(9)}$, Benedetti Panici et al. ${ }^{(10)}$ ). Surgical staging is the only way to determine indications for adjuvant treatment (radiotherapy and/or systemic therapy). According to PORTEC-3 trial ${ }^{(11)}$, chemotherapy is appropriate for stage III endometrial cancer (including lymph node metastases) and helps improve 5-year disease-free survival (69.3\% vs. $58.0 \%$; $95 \%$ CI $0.45-0.97$, $p=0.032$ ).

Sentinel lymph node concept is a promising alternative to systemic lymphadenectomy, as confirmed in SENTI-ENDO ${ }^{(12)}$ and FIRES ${ }^{(13)}$ prospective multicenter trials. Sentinel lymph node identification rate was $86-88.8 \%$ with $2.4-3 \%$ of false negative results, which led to upstaging of low and intermediate risk groups in $10 \%$ and $15 \%$ of patients, respectively. Holloway et al. ${ }^{(14)}$ reported recommendations of SGO consensus dedicated to sentinel lymph nodes in endometrial cancer, which was considered the most accurate method of lymph node assessment.

An analysis of a prospective multicenter trial FRANCOGYN $^{(15)}$ (2017; $N=181$; intermediate and high risk group of patients according to ESGO-ESMO-ESTRO) showed that 5 -year overall survival rate was $85 \%$ for N0 cases, $71.8 \%$ - for $\mathrm{N} 1$ cases, and $36 \%$ for patients without surgical staging of lymph nodes $(p=0.047)$. Recurrence rate was $15.7 \%$ for patients with negative lymph nodes, $25.8 \%$ for positive lymph nodes, and $25 \%$ for those without surgical staging. Lymph node involvement was diagnosed at the time of recurrence in $23.1 \%, 37.5 \%$ and $66.7 \%$ cases, respectively.

\begin{tabular}{|c|c|c|c|c|c|c|}
\hline \multirow{2}{*}{ Treatment* } & \multicolumn{6}{|c|}{ Cancer-specific survival (excluding stage III) } \\
\cline { 3 - 8 } & & $\boldsymbol{n}$ & $\mathbf{3 - y e a r}[\%]$ & Median & $\mathbf{9 5 \%}$ Cl & $\boldsymbol{p}$ \\
\hline \multirow{2}{*}{ Surgery } & Yes & 32 & 28.1 & 22 & $9.5-34.5$ & \multirow{2}{*}{0.997} \\
\cline { 2 - 7 } & No & 21 & 19.0 & 21 & $7.5-34.5$ & \\
\hline \multirow{2}{*}{ Radiotherapy } & Yes & 41 & 29.3 & 27 & $23.2-30.8$ & \multirow{2}{*}{0.024} \\
\cline { 2 - 7 } & No & 12 & 8.3 & 13 & $6.2-19.8$ & \\
\hline \multirow{2}{*}{ Chemotherapy } & Yes & 9 & 11.1 & 16 & $13.1-18.9$ & \multirow{2}{*}{0.518} \\
\cline { 2 - 6 } & No & 44 & 27.3 & 26 & $19.5-32.5$ & \\
\hline * No cancer-related treatment in 3 patients. \\
\hline
\end{tabular}

Tab. 4. Survival data among dead patients with different components of endometrial cancer treatment 
Sentinel lymph node concept allows moving toward complete surgical staging of endometrial cancer with minimal morbidity, at least without impairment of oncological prognosis. It may be a helpful tool to improve treatment outcomes as it helps avoid understaging and decreases cancerrelated mortality.

\section{CONCLUSION}

The same rates of cancer-specific survival may indicate that the presented cases of apparent early stage endometrial cancer were understaged and consequently undertreated. Further studies including more patients are needed.

\section{Conflict of interest}

None.

\section{References}

1. Morice P, Leary A, Creutzberg C et al.: Endometrial cancer. Lancet 2016; 387: 1094-1108.

2. Lewin SN, Herzog TJ, Barrena Medel NI et al.: Comparative performance of the 2009 International Federation of Gynecology and Obstetrics' staging system for uterine corpus cancer. Obstet Gynecol 2010; 116: 1141-1149.

3. Brown AP, Gaffney DK, Dodson MK et al.: Survival analysis of endometrial cancer patients with positive lymph nodes. Int J Gynecol Cancer 2013; 23: 861-868.

4. SGO Clinical Practice Endometrial Cancer Working Group; Burke WM, Orr J, Leitao M et al.; Society of Gynecologic Oncology Clinical Practice Committee: Endometrial cancer: a review and current management strategies: part I. Gynecol Oncol 2014; 134: 385-392.

5. Colombo N, Creutzberg C, Amant $\mathrm{F}$ et al.; ESMO-ESGO-ESTRO Endometrial Consensus Conference Working Group: ESMOESGO-ESTRO Consensus Conference on Endometrial Cancer: diagnosis, treatment and follow-up. Ann Oncol 2016; 27: 16-41.
6. Creasman WT, Morrow CP, Bundy BN et al.: Surgical pathologic spread patterns of endometrial cancer. A Gynecologic Oncology Group Study. Cancer 1987; 60 (Suppl): 2035-2041.

7. Mariani A, Dowdy SC, Cliby WA et al.: Prospective assessment of lymphatic dissemination in endometrial cancer: a paradigm shift in surgical staging. Gynecol Oncol 2008; 109: 11-18.

8. Widschwendter P, Bauer E, De Gregorio N et al.: Influence of prognostic factors on lymph node involvement in endometrial cancer: a single-center experience. Int J Gynecol Cancer 2018; 28: 1145-1152.

9. Barton DPJ, Naik R, Herod J: Efficacy of systematic pelvic lymphadenectomy in endometrial cancer (MRC ASTEC trial): a randomized study. Int J Gynecol Cancer 2009; 19: 1465.

10. Benedetti Panici P, Basile S, Maneschi F et al.: Systematic pelvic lymphadenectomy vs. no lymphadenectomy in early-stage endometrial carcinoma: randomized clinical trial. J Natl Cancer Inst 2008; 100: 1707-1716.

11. de Boer SM, Powell ME, Mileshkin L et al.; PORTEC study group: Adjuvant chemoradiotherapy versus radiotherapy alone for women with high-risk endometrial cancer (PORTEC-3): final results of an international, open-label, multicentre, randomised, phase 3 trial. Lancet Oncol 2018; 19: 295-309.

12. Ballester $M$, Dubernard G, Lécuru F et al.: Detection rate and diagnostic accuracy of sentinel-node biopsy in early stage endometrial cancer: a prospective multicentre study (SENTI-ENDO). Lancet Oncol 2011; 12: 469-476.

13. Rossi EC, Kowalski LD, Scalici J et al.: A comparison of sentinel lymph node biopsy to lymphadenectomy for endometrial cancer staging (FIRES trial): a multicentre, prospective, cohort study. Lancet Oncol 2017; 18: 384-392.

14. Holloway RW, Abu-Rustum NR, Backes FJ et al.: Sentinel lymph node mapping and staging in endometrial cancer: a society of gynecologic oncology literature review with consensus recommendations. Gynecol Oncol 2017; 146: 405-415.

15. Ouldamer L, Bendifallah S, Body $\mathrm{G}$ et al.: Call for surgical nodal staging in women with ESMO/ESGO/ESTRO high-intermediate risk endometrial cancer: a multicentre cohort analysis from the FRANCOGYN study group. Ann Surg Oncol 2017; 24: 1660-1666. 